\title{
ENTOMOPATHOGENIC FUNGI ON THE CONTROL OF Sphenophorus levis IN SUGARCANE CROP
}

\author{
Fernando Belezini Vinha ${ }^{1 *}$, Luis Arnaldo de Assis Delfanti ${ }^{2}$, Victor Dias Pagliarani ${ }^{2}$, \\ Vitor Sartori Ferreira ${ }^{2}$, Alexandre de Sene Pinto ${ }^{2}$
}

SAP 24426 Received: 02/04/2020 Accepted: 03/08/2020

Sci. Agrar. Parana., Marechal Cândido Rondon, v. 19, n. 3, jul./sep., p. 280-288, 2020

\begin{abstract}
Brazil is the largest producer of sugarcane crop in the world,but its production can be highly affected by the pest Sphenophorus levis. The entomopathogenic fungi Metarhizium anisopliae and Beauveria bassiana can be used for the control of this pest, but are not always effective in the field, lacking information on application methods, doses and formulations. We evaluate the efficacy of M. anisopliae IBCB 425 and B.bassiana IBCB 66 in controlling S. levis and other soil pests at sugarcane crop. The bioassay was conducted in a split plot design, where each of the 4 treatments were repeated 5 times and distributed over an area of $5.000 \mathrm{~m}^{2}$. The treatments for both fungi consisted of: Wettable powder (WP) formulation $225 \mathrm{~g}$ conidia ha ${ }^{-1}$, WP formulation $450 \mathrm{~g}$ conidia $\mathrm{ha}^{-1}$, granule (GR) formulation $10 \mathrm{Kg} \mathrm{ha}^{-1}$ and Control (no fungal application). WP fungi formulations were applied to the ratoon with a tractor using a ratoon cutter and an pesticide applicator. The GR fungi formulation was manually applied on the ratoons. The evaluations were performed after 21, 60 and 100 days of fungi application. B. Bassiana fungus reduced the pest population but did not differ from the control, however for $M$. Anisopliae fungus there were significant differences between treatments on damaged stems. The fungus M. anisopliae was effective in controlling S. levis larvae and adults in the field and WP formulation had faster action than the GR, the dose of 225 $\mathrm{g}$ conidia ha ${ }^{-1}$ was enought to reduce $S$. levis population.
\end{abstract}

Keywords: soil pests, microbial control, biological control, Scarabaeidae, sugarcane weevil.

\section{FUNGOS ENTOMOPATOGENICOS NO CONTROLE DE Sphenophorus levis EM CANA-DE-AÇUCAR}

\begin{abstract}
RESUMO - O Brasil é o maior produtor de cana-de-açúcar do mundo, mas sua produção pode ser afetada pela praga Sphenophorus levis. Os fungos entomopatogênicos Metarhizium anisopliae e Beauveria bassiana podem ser utilizados no controle desta praga, mas nem sempre são eficazes no campo, faltando informações sobre métodos de aplicação, doses e formulações. Nesse estudo foi avaliado a eficácia de M. anisopliae IBCB425 e B.bassiana IBCB66 no controle de S. levis na cana-de-açúcar. O bioensaio foi conduzido em um esquema de parcelas subdivididas, onde cada um dos 4 tratamentos foi repetido 5 vezes e distribuído por uma área de $5.000 \mathrm{~m}^{2}$. Os tratamentos para ambos os fungos consistiram em: formulação pó molhavel (WP) $225 \mathrm{~g}$ de conídios ha ${ }^{-1}$, formulação WP 450g de conídios ha ${ }^{-1}$, formulação granulada (GR) $10 \mathrm{~kg} \mathrm{de} \mathrm{ha}^{-1} \mathrm{e}$ Controle (sem fungos). As formulações de fungos WP foram aplicadas à cana-soca com um trator, utilizando um cortador de soqueira e um aplicador de pesticidas. A formulação de fungos GR foi aplicada manualmente nas soqueiras. As avaliações foram realizadas após 21, 60 e 100 dias das aplicações. O fungo B. Bassiana reduziu a população de S.levis, mas não diferiu do controle, porém para o fungo M. Anisopliae houve diferenças significativas entre os tratamentos em hastes danificadas por S.levis. O fungo M. anisopliae foi eficaz no controle de larvas e adultos de S.levis no campo e a formulação WP teve ação mais rápida que a GR, a dose de $225 \mathrm{~g}$ de conídios ha ${ }^{-1}$ foi suficiente para reduzir a população de $S$. levis.
\end{abstract}

Palavras-chave: pragas do solo, controle microbiano, controle biológico, Scarabaeidae, gorgulho da cana-de-açúcar.

\section{INTRODUCTION}

The genus Sphenophorus is a complex of species that damage several crops of economic importance. In the United States there are more than 64 species of this genus, which 20 have been recorded in Florida (WOODRUFF, 2001). This genus is cosmopolitan and pest species are reported in all zoogeographic regions of the globe, including sugarcane crop (ALONSO-ZARAZAGA and LYAL 2002; GÜLTEKIN, 2013; HALL, 1988; PEREZ et al., 2014).
The sugarcane weevil, Sphenophorus levis (Coleoptera Curculionidae), is the most important and harmful soil pest to sugarcane (Saccharum officinarum L.) crop in Brazil, mainly in the state of São Paulo. The larvae of this insect cause great damage, the damage is reflected in the number, size and diameter of final stalks for harvest, in some places, 50 to $60 \%$ of attacked tillers have been detected with losses around 20 to 30 tons of sugarcane per hectare, consequently reducing the longevity of sugarcane plants (LEITE et al., 2006; PINTO et al., 2009). This pest was first collected in Brazil on bromeliads, damaging 
them, and in 1977 was reported on sugarcane crop. Initially restricted to the region of Piracicaba - SP, in 2006 it was already in 53 municipalities of São Paulo and Minas Gerais states, causing 50-60\% of tillers death on sugarcane with five to seven months of growth (PINTO et al., 2009; PRECETTI and ARRIGONI 1990).

These insects attack healthy tillers and stalks and prefer clear, clayey and moist soils (PINTO et al., 2009). It has a restricted flight capacity, suggesting that long-range insect dispersal occurs through seedlings taken from an infested site. Adults walk slowly allowing dispersion from one field to another neighbor, but the larval phase is the one that causes the most damage to the crop (ALMEIDA, 2005; LEITE et al., 2006). Plant damage is observed in the below-ground rhizome, where the larva feeds and shelters, opening circular and longitudinal galleries at the base of the bud. This attack results in leaf yellowing and tiller death (DEGASPARI et al., 1977). The most used method to control $S$. levis is the mechanical destruction of the ratoon during the planting period (time of sugarcane reform), trying to expose the larvae to their predators and the rhizomes drying. It is also recommended to eliminate weeds that can serve as food source for larvae (PRECETTI and ARRIGONI, 1990).

However, this practice presents satisfactory results only in the first harvest, because many insect larvae can survive by feeding on the organic matter left in the field after the destruction of the ratoons, not affecting the adult forms of this insect (ALMEIDA, 2005). The agrochemicals used to control this pest is not advised, as it may not always function well as seen by Evangelista et al. (2017), in addition, most insecticides used have high toxicity and can reduce natural enemies concomitantly during applications. One of the strategies investigated against soil pests, especially in Europe, is the combined use of entomopathogenic fungi and nematodes to control these beetles and other pests, the results usually present satisfactory levels of control (ANSARI et al., 2004, ANSARI et al., 2006, ANSARI et al., 2008, ANSARI et al., 2010; BARBERCHECK and KAYA 1991; BARBERCHEK and KAYA 1990; SHAPIRO-ILAN et al., 2004)

In Brazil, some studies have tested the efficiency of entomopathogenic nematodes, bacteria and fungi in the control of S. levis in the field (LEITE et al., 2012; VINHA et al., 2019). However, they did not obtain such expressive results in the control of S. levis, Cícero et al. (2009) selected Bacillus thuringiensis strains and obtained up to $70 \%$ mortality of S. levis larvae, but the study was carried out under laboratory conditions and with artificial diets. So far any products have been launched on the market for the biocontrol of this pest, except for entomopathogenic fungi that already have several products available on the market, but due to the lack of studies and the difficulty in establishing efficient application methods and adequate concentrations of these fungi, the desired efficiency in biocontrol of this pest does not exist yet. Therefore, new strategies to increase the biocontrol of this pest should be evaluated. In this context, this study approached the use of entomopathogenic fungi applied with a ratoon-cutter, that increases the insect contact area with these fungi, facilitating the biocontrol of S. levis larvae and adults in the field.

\section{MATERIAL AND METHODS Study site}

The bioassays were installed in November 3 and 4, 2014, at Vista Alegre mill (Itapetininga - São Paulo state), and were conducted from November 3, 2014 to April 22, 2015 on commercial sugarcane, SP81- 3250 variety (ratoon-cane), with one month of development.

\section{Fungal isolate and production of inoculum}

Two strains of entomopathogenic fungi were used in the experiments, the strains IBCB $425 \mathrm{M}$. anisopliae and IBCB-66 B. bassiana was gently provided by Instituto Biológico de São Paulo, Brazil. The fungal isolates were cultured in Potato Dextrose Agar (PDA, KASVI) medium and $0.1 \%$ stock antibiotics was added. The stock antibiotic solution consisted of $0.02 \mathrm{~g}$ each of tetracycline, streptomycin and penicillin, dissolved in $10 \mathrm{ml}$ sterile, distilled water, filter-sterilized through a $0.2 \mathrm{~mm}$ filter. The medium was added on Petri dishes and incubated in a B.O.D chamber at $26 \pm 1^{\circ} \mathrm{C}$ with full darkness for 7 to 10 days.

Subsequently, the solid fermentation was carried out to increase the amount of inoculum used for the bioassays. For the solid fermentation were used $500 \mathrm{~mL}$ capacity screw-cap borosilicate glass bottles (Schott Mark) containing 100 grams of parboiled rice type 1, purchased by local retailers. Initially, the substrate was hydrated with $200 \mathrm{~mL}$ of distilled water and kept at room temperature for $50 \mathrm{~min}$. Thereafter, the rice was sieved to remove excess of water and returned to the Schott flasks to be autoclaved at $120^{\circ} \mathrm{C}$ for $20 \mathrm{~min}$.

The inoculum of each fungal isolate was prepared by scraping the conidia present in the PDA medium and diluted in sterilized distilled water with $0.01 \%(\mathrm{v} / \mathrm{v})$ surfactant (Tween $80^{\circledR}$, Vetec Química Fina Ltda., Rio de Janeiro, Brazil). The inoculation of the flasks was done in an aseptic laminar flow chamber with the addition of $5 \mathrm{~mL}$ of the conidia suspension of each isolate adjusted to $1 \mathrm{x}$ $10^{8}$ conidia $\mathrm{mL}^{-1}$, and thereafter all flasks were incubated at $20^{\circ} \mathrm{C}, 9 \pm 2 \%$ relative humidity $(\mathrm{RH})$ and full darkness for 10 days. Subsequently, for WP formulation, conidia were extracted from the rice by sieving, and then mixed with talcum powder and maize starch powder, GR formulation was made with sporulated parboiled rice.

The conidia concentration was adjusted throughout counting in a Neubauer chamber with a light microscope. The viability of all fungus spores used in the bioassays exceeded $88 \%$.

\section{Field plots and experimental design}

The experimental design was carried out in split plots, and each of the 4 treatments for each fungus was repeated 5 times. Each plot had the dimensions of $50 \times 100$ $\mathrm{m}\left(5.000 \mathrm{~m}^{2}\right)$. To assemble the bioassays, the fungi were 
evaluated separately, in separated areas, where the treatments for each type of fungus are described in Table 1.

Fungi were applied one dose at a time in the late afternoon. For the WP formulation, $90 \mathrm{~L}$ of water per hectare was used, a New Holland tractor model-7630 with 105 horsepower, 4x4, and a $300 \mathrm{~L}$ insecticide reservoir applicator, that had cutting discs, where they opened the ratoons in half to facilitate the conidia penetration and right behind there were nozzles that distributed the product, this agricultural implement is known as "ratoon cutter". For the GR formulation, the application was done manually, distributing the grains + conidia over the clumps. The evaluations were performed before the application and after 21, 60 and 100 days. At four randomly chosen points within each plot, all basal internodes of one linear meter were surveyed. The number of basal stem internodes and the number of those with symptoms of $S$. levis attack, number of larvae, pupae or adults of $S$. levis and the presence of other organisms such as Euetheola humilis (Burmeister) (Coleoptera Scarabaeidae) and Heterotermes tenuis (Hagen) (Isoptera Rhinotermitidae).

TABLE 1 - Fungi treatments with their formulations and concentrations used in bioassays.

\begin{tabular}{|c|c|c|}
\hline Treatments & Formulations & Concentrations \\
\hline M. anisopliae IBCB 425 & WP* & $225 \mathrm{~g}_{\text {conidia }} \mathrm{ha}^{-1}$ \\
\hline M. anisopliae IBCB 425 & WP & $450 \mathrm{~g}$ conidia ha ${ }^{-1}$ \\
\hline M. anisopliae IBCB 425 & $\mathrm{GR} * *$ & $10 \mathrm{Kg} \mathrm{ha}^{-1}$ \\
\hline Control & None & None \\
\hline B. bassiana IBCB 66 & WP & 225 g conidia ha $^{-1}$ \\
\hline B. bassiana IBCB 66 & WP & $450 \mathrm{~g}$ conidia $\mathrm{ha}^{-1}$ \\
\hline B. bassiana IBCB 66 & GR & $10 \mathrm{Kg} \mathrm{ha}^{-1}$ \\
\hline Control & None & None \\
\hline
\end{tabular}

${ }^{*} \mathrm{WP}=$ wettable powder (maize starch + talc) ${ }^{* *} \mathrm{GR}=$ granule (parboiled rice).

At harvest, 10 random stalks were chosen at each of the 4 points in the plot, these stalks were weighed in bundles of 10. As there were significant differences between treatments for the average percentage of damaged stems, the average mortality percentage for each treatment was calculated and the value corrected $(\% \mathrm{RC})$ by the formula of Henderson and Tilton (1955), which takes into account the population for each treatment before and after application (Equation 1).

$$
\% \mathrm{RC}=100-\left(\frac{(P c \times T d)}{(C d \times P t)}\right) \times 100 \quad(\text { Equation } 1)
$$

Where:

$P c=$ indicates the number in the prior control,

$C d=$ number in the control on date,

$T d=$ number in the treatment on date and

$P t=$ number in the prior treatment.

\section{Data analysis}

The data obtained from all evaluated parameters were transformed into means, compared to each other and submitted to the average comparison analysis by Tukey test, at 5\% significance level. All statistical calculations were performed by Statistica for Windows (STATSOFT, 1996).

\section{RESULTS AND DISCUSSION Metarhizium anisopliae evaluation}

In 11/03/2014 (previous evaluation), there was an average infestation of $35.27 \%$ attacked stalks, but presented only 0.57 and 0.66 of $S$. levis larvae and adults, respectively, in stalks and soils of 1 linear meter of sugarcane. Until 21 days after fungal application there were no significant differences between treatments regarding the average percentage of stalks attacked by $S$. levis (Figure 1). At 60 days after treatment, the control showed the highest value, differing statistically from the liquid-applied $M$. anisopliae treatments with the WP formulation. At 100 days after application, the control presented the highest value and differed from the other treatments. The fungus in the liquid formulation (WP), at the two doses tested, reduced above $80 \%$ of the damage on stems at 60 days after application, as did the granulated formulation (GR) at 100 days (Figure 2).

Regarding the average number of $S$. levis larvae per stem and soil in a linear meter in the sugarcane planting line, there were significant differences between treatments at 21 days after application, where treatment with M. Anisopliae WP 450 presented the highest value, differing from the other treatments with the fungus and not differing from the control, which presented an intermediate value (Figure 3). At 60 days after application, treatment with M. Anisopliae WP 225 presented the lowest value, differing statistically only from the control, which presented the highest value. 
Entomopathogenic fungi...

VINHA, F. B. et al. (2020)

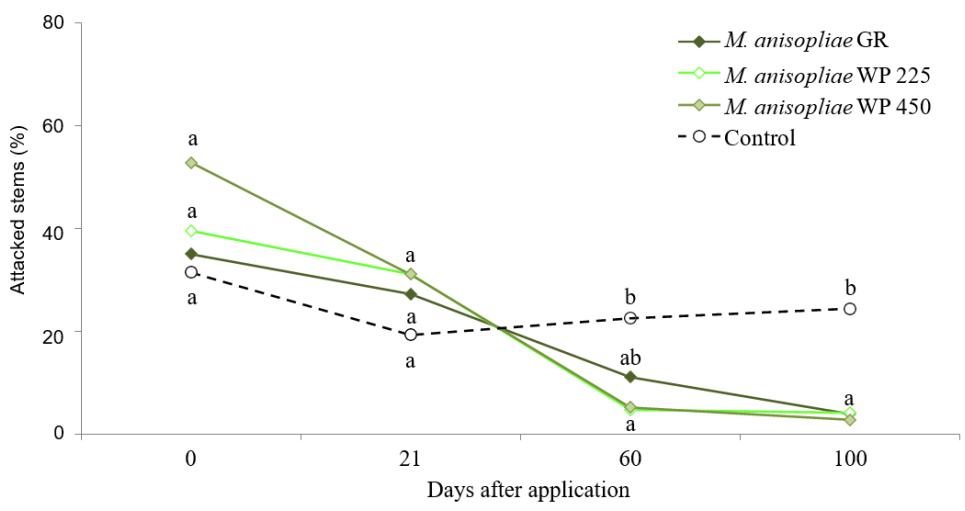

FIGURE 1 - Average percentage of sugarcane stalks attacked by Sphenophorus levis larvae after application of the fungus Metarhizium anisopliae IBCB-425 with the formulations GR and WP in sugarcane after harvest. Points followed by the same letter do not differ from each other by the Tukey's test $(\mathrm{p} \leq 0.05)$.

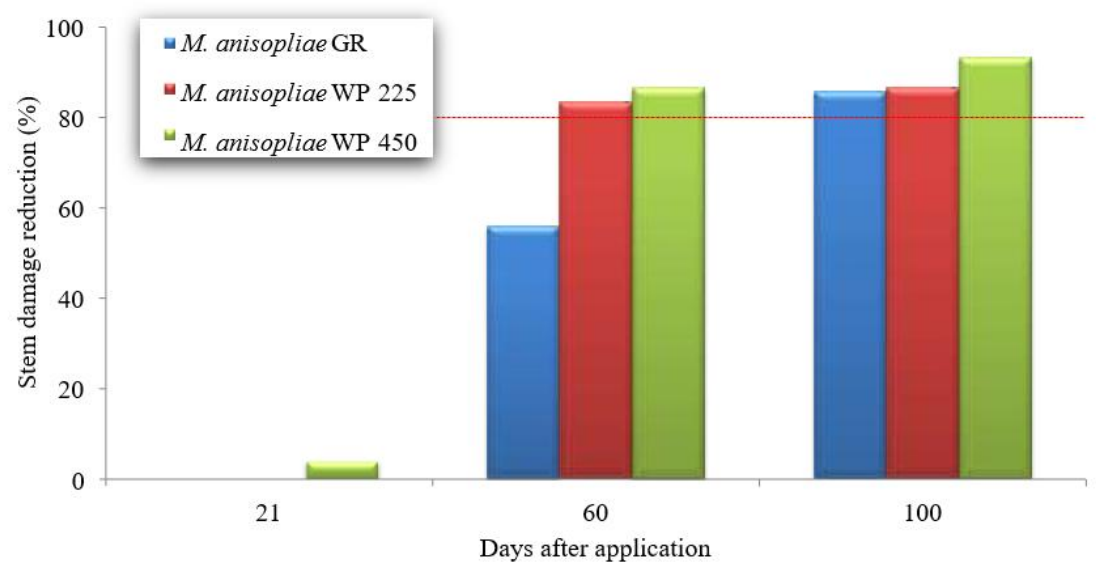

FIGURE 2 - Average percentage of corrected reduction of damage to sugarcane stems attacked by Sphenophorus levis larvae after application of the fungus Metarhizium anisopliae IBCB 425 in the post-harvest harvesting, with GR and WP formulations.

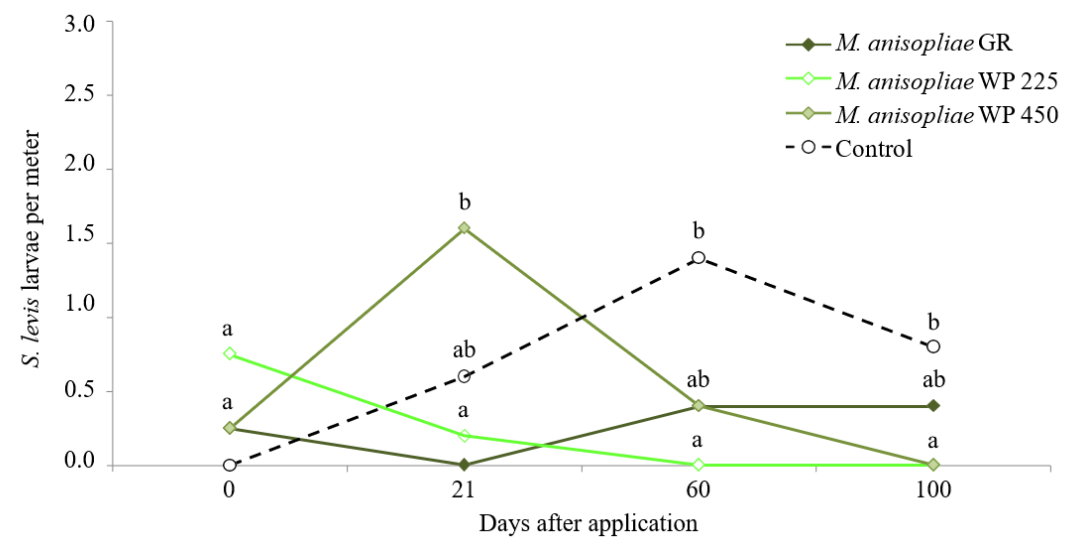

FIGURE 3 - Average number of Sphenophorus levis larvae per stalk or soil of 1 linear meter after application of the fungus Metarhizium anisopliae IBCB 425 with the formulations GR and WP in sugarcane, after harvest. Points followed by the same letter do not differ from each other by the Tukey's test $(\mathrm{p} \leq 0.05)$.

At 100 days after application, M. anisopliae WP 225 and 450 treatments presented the lowest values, differing only from the control. The M. anisopliae GR treatment presented the highest value among the fungal treatments and did not differ from the control (Figure 3). There were no significant differences between treatments on the average number of $S$. levis pupae at stalks and soil in one linear meter (Table 2). However, on the average number of adults of S. levis, at 100 days after fungal application, all treatments were null and significantly different from the control, which found $0.80 \pm 0.37$ insects $\mathrm{m}^{-1}$ (Table 3 ). 
Entomopathogenic fungi...

VINHA, F. B. et al. (2020)

TABLE 2 - Average number of Sphenophorus levis pupae at stems or soil in 1 linear meter after application of the fungus Metarhizium anisopliae IBCB 425 with the formulations GR and WP in sugarcane, after harvest.

\begin{tabular}{lcclr}
\hline Treatments & \multicolumn{4}{c}{ Days after application } \\
\cline { 2 - 5 } & 0 & 21 & 60 & 100 \\
\hline M. anisopliae GR & $0.50 \pm 0.29 \mathrm{a} *$ & $0.00 \pm 0.00 \mathrm{a}$ & $0.20 \pm 0.20 \mathrm{a}$ & $0.00 \pm 0.00 \mathrm{a}$ \\
M. anisopliae WP 225 & $0.25 \pm 0.25 \mathrm{a}$ & $0.00 \pm 0.00 \mathrm{a}$ & $0.00 \pm 0.00 \mathrm{a}$ & $0.20 \pm 0.20 \mathrm{a}$ \\
$M$. anisopliae WP 450 & $0.25 \pm 0.25 \mathrm{a}$ & $0.00 \pm 0.00 \mathrm{a}$ & $0.00 \pm 0.00 \mathrm{a}$ & $0.00 \pm 0.00 \mathrm{a}$ \\
Control & $0.50 \pm 0.29 \mathrm{a}$ & $0.00 \pm 0.00 \mathrm{a}$ & $0.00 \pm 0.00 \mathrm{a}$ & $0.00 \pm 0.00 \mathrm{a}$ \\
\hline
\end{tabular}

*Averages followed by the same letter in the column do not differ from each other by the Tukey's test $(\mathrm{p} \leq 0.05)$.

TABLE 3 - Average number of Sphenophorus levis adults at stems or soil in 1 linear meter after application of the fungus Metarhizium anisopliae IBCB 425 with the formulations GR and WP in sugarcane, after harvest.

\begin{tabular}{lcccr}
\hline \multirow{2}{*}{ Treatments } & \multicolumn{4}{c}{ Days after application } \\
\cline { 2 - 5 } & 0 & 21 & 60 & 100 \\
\hline M. anisopliae GR & $1.25 \pm 1.25 \mathrm{a}^{*}$ & $0.40 \pm 0.24 \mathrm{a}$ & $0.20 \pm 0.20 \mathrm{a}$ & $0.00 \pm 0.00 \mathrm{~b}$ \\
M. anisopliae WP 225 & $1.25 \pm 0.95 \mathrm{a}$ & $0.00 \pm 0.00 \mathrm{a}$ & $0.00 \pm 0.00 \mathrm{a}$ & $0.00 \pm 0.00 \mathrm{~b}$ \\
M. anisopliae WP 450 & $0.75 \pm 0.48 \mathrm{a}$ & $0.40 \pm 0.40 \mathrm{a}$ & $0.00 \pm 0.00 \mathrm{a}$ & $0.00 \pm 0.00 \mathrm{~b}$ \\
Control & $0.25 \pm 0.25 \mathrm{a}$ & $0.40 \pm 0.40 \mathrm{a}$ & $0.00 \pm 0.00 \mathrm{a}$ & $0.80 \pm 0.37 \mathrm{a}$ \\
\hline
\end{tabular}

*Averages followed by the same letter in the column do not differ from each other by the Tukey's test $(\mathrm{p} \leq 0.05)$.

There were also no differences on the average number of E. humilis larvae (Table 3). S. Levis pupae and $E$. humilis larvae occurred in low amounts throughout the trial, except for $E$. humilis at 100 days after fungal application (Table 4). Few specimens of pupae and adults of E. humilis, termites and other soil organisms were observed in bioassay.

TABLE 4 - Average number of Euetheola humilis larvae at stems or soil in 1 linear meter after application of the fungus Metarhizium anisopliae IBCB 425 with the formulations GR and WP in sugarcane, after harvest.

\begin{tabular}{lccrr}
\hline Treatments & \multicolumn{4}{c}{ Days after application } \\
\cline { 2 - 5 } & 0 & 21 & 60 & 100 \\
\hline M. anisopliae GR & $0.50 \pm 0.29 \mathrm{a} *$ & $0.00 \pm 0.00 \mathrm{a}$ & $0.20 \pm 0.20 \mathrm{a}$ & $1.80 \pm 0.92 \mathrm{a}$ \\
M. anisopliae WP 225 & $0.50 \pm 0.50 \mathrm{a}$ & $0.40 \pm 0.40 \mathrm{a}$ & $0.40 \pm 0.24 \mathrm{a}$ & $1.20 \pm 0.58 \mathrm{a}$ \\
M. anisopliae WP 450 & $0.50 \pm 0.50 \mathrm{a}$ & $0.20 \pm 0.20 \mathrm{a}$ & $0.20 \pm 0.20 \mathrm{a}$ & $0.20 \pm 0.20 \mathrm{a}$ \\
Control & $0.50 \pm 0.29 \mathrm{a}$ & $0.00 \pm 0.00 \mathrm{a}$ & $0.20 \pm 0.20 \mathrm{a}$ & $1.20 \pm 0.73 \mathrm{a}$ \\
\hline
\end{tabular}

*Averages followed by the same letter in the column do not differ from each other by the Tukey's test $(\mathrm{p} \leq 0.05)$.

\section{Beauveria bassiana evaluation}

The average infestation of $S$. levis at the assay site $(11 / 03 / 2014)$ was $35.27 \%$ of attacked stalks but had only 0.57 and $0.66 \mathrm{~S}$. levis larvae and adults, in stalks and soil for 1 linear meter on the planting line. Regarding the average percentage of stalks attacked by $S$. levis, there were no significant differences between treatments at any evaluation date. Only at 100 days after fungus application presented differences $(\mathrm{P}=0.12)$ between control and treatment with $B$. Bassiana WP 450, which had the highest values, and the other treatments (Figure 4).

Even so, the corrected mean percentage of damaged stem was calculated, showing that at 60 days after application, the treatment with B. Bassiana WP 450 showed efficiency above $80 \%$, dropping significantly at 100 days (Figure 5). The treatments B. Bassiana WP 225 and GR showed efficiency around $60 \%$, with these values increasing from 60 to 100 days after application (Figure 5). Although there was no reduction in stem damage, there were significant differences between treatments on the average number of S.levis larvae per linear meter at 60 days after fungus application (Figure 6). On that date, $B$. Bassiana WP 450 and GR treatments presented the lowest values, statistically differing from the control, which presented the highest value. This result for S. levis larvae agrees with the calculated efficiency of the micoinsecticide B. Bassiana WP 450 observed 60 days after application. 
Entomopathogenic fungi...

VINHA, F. B. et al. (2020)

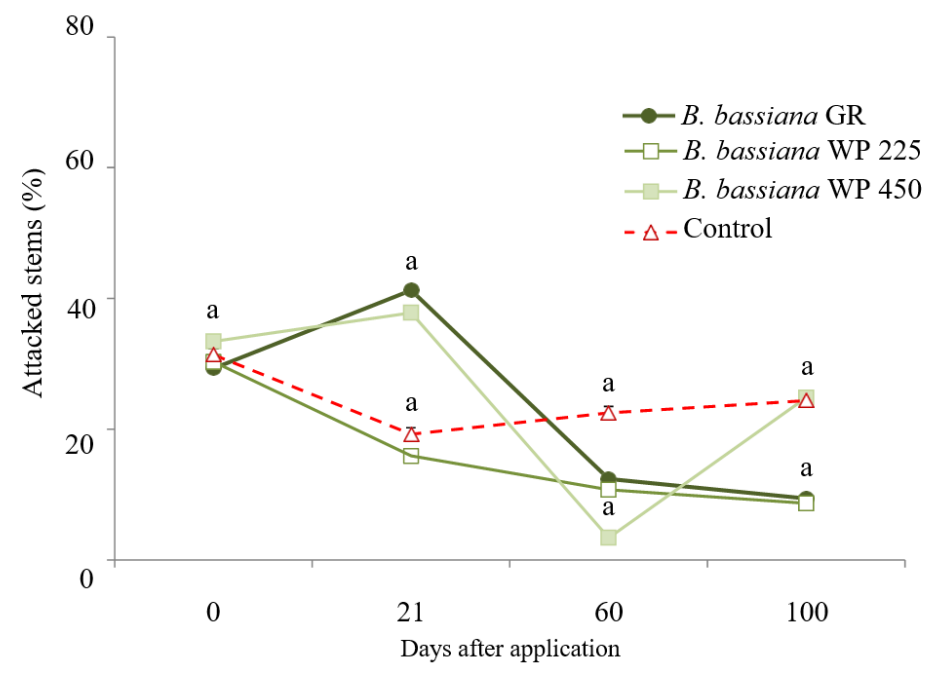

FIGURE 4 - Average percentage of sugarcane stalks attacked by Sphenophorus levis larvae after application of the fungus Beauveria bassiana IBCB 66 with the formulations GR and WP in sugarcane after harvest. Points followed by the same letter do not differ from each other by the Tukey's test $(\mathrm{p} \leq 0.05)$.

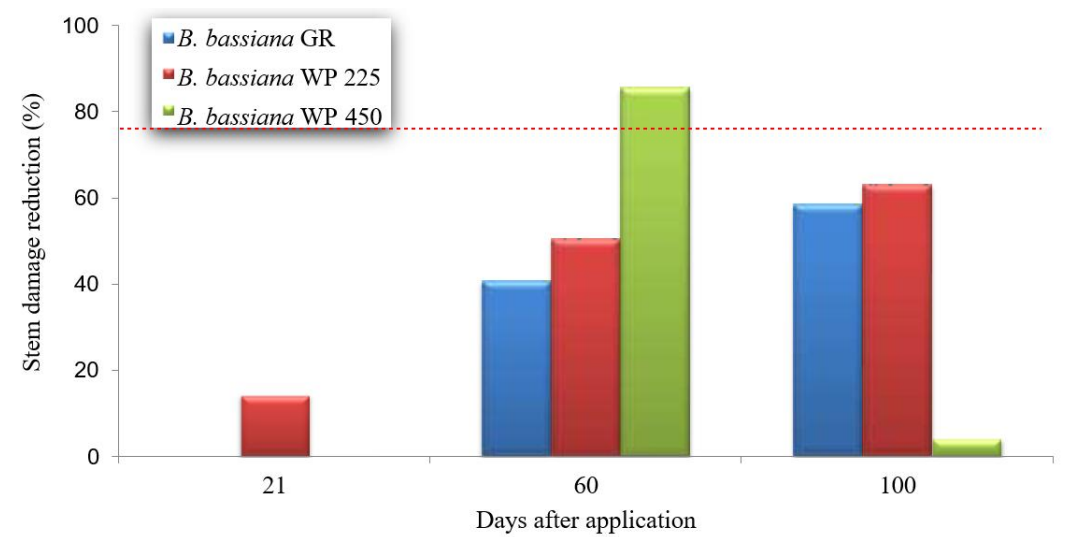

FIGURE 5 - Average percentage of corrected reduction of damage to sugarcane stems attacked by Sphenophorus levis larvae after application of the fungus Beauveria bassiana IBCB 66 in the post-harvest harvesting, with GR and WP formulations.

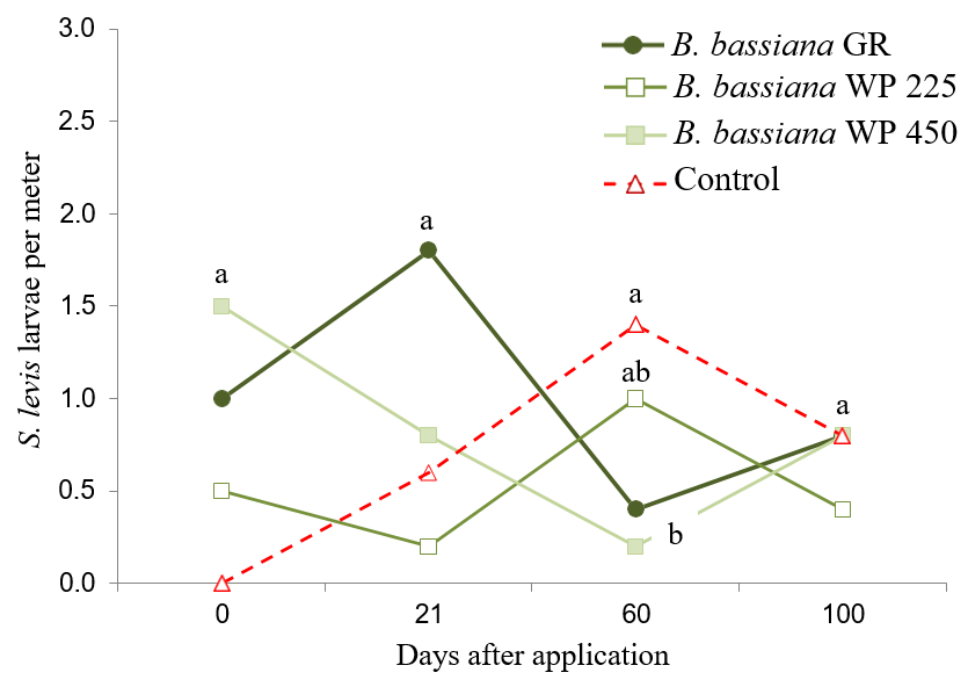

FIGURE 6 - Average number of Sphenophorus levis larvae per stalk or soil of 1 linear meter after application of the fungus Beauveria bassiana IBCB 66 with the formulations GR and WP in sugarcane, after harvest. Points followed by the same letter do not differ from each other by the Tukey's test $(\mathrm{p} \leq 0.05)$. 
Regarding the average number of pupae and adults of $S$. levis per linear meter, there were no significant differences between treatments at any evaluation date (Tables 5 and 6). It is noteworthy that the insect quantities found were also low, at 100 days after fungus application, the control presented the highest value of adults per meter differing statistically from the other treatments only if $\mathrm{P}=$ 0.09, which would indicate the fungal treatments efficiency also on the adults of $S$. levis. Regarding the average number of $E$. humilis larvae, there were no significant differences between treatments at any evaluation date. However, the amounts of larvae found from this insect were low (Table 7). The B. bassiana fungus applied directly to the rows with a ratoon cutter was effective in controlling larvae up to 60 days but did not reduce damage to sugarcane ratoons during crop development.

TABLE 5 - Average number of Sphenophorus levis pupae at stems or soil in 1 linear meter after application of the fungus Beauveria bassiana IBCB 66 with the formulations GR and WP in sugarcane, after harvest.

\begin{tabular}{lcccr}
\hline Treatments & \multicolumn{4}{c}{ Days after application } \\
\cline { 2 - 5 } & 0 & 21 & 60 & 100 \\
\hline B. bassiana GR & $0.25 \pm 0.25 \mathrm{a}^{*}$ & $0.40 \pm 0.40 \mathrm{a}$ & $0.00 \pm 0.00 \mathrm{a}$ & $0.20 \pm 0.20 \mathrm{a}$ \\
B. bassiana WP 225 & $1.25 \pm 0.95 \mathrm{a}$ & $0.20 \pm 0.20 \mathrm{a}$ & $0.00 \pm 0.00 \mathrm{a}$ & $0.20 \pm 0.20 \mathrm{a}$ \\
B. bassiana WP 450 & $1.00 \pm 0.41 \mathrm{a}$ & $0.00 \pm 0.00 \mathrm{a}$ & $0.00 \pm 0.00 \mathrm{a}$ & $0.00 \pm 0.00 \mathrm{a}$ \\
Control & $0.50 \pm 0.29 \mathrm{a}$ & $0.00 \pm 0.00 \mathrm{a}$ & $0.00 \pm 0.00 \mathrm{a}$ & $0.00 \pm 0.00 \mathrm{a}$ \\
\hline
\end{tabular}

*Averages followed by the same letter in the column do not differ from each other by the Tukey's test $(\mathrm{p} \leq 0.05)$.

TABLE 6 - Average number of Sphenophorus levis adults at stems or soil in 1 linear meter after application of the fungus Beauveria bassiana IBCB 66 with the formulations GR and WP in sugarcane, after harvest.

\begin{tabular}{lcccr}
\hline Treatments & \multicolumn{5}{c}{ Days after application } \\
\cline { 2 - 5 } & 0 & 21 & $0.00 \pm 0.00 \mathrm{a}$ & $0.00 \pm 0.00 \mathrm{a}$ \\
B. bassiana GR & $0.75 \pm 0.48 \mathrm{a}^{*}$ & $0.40 \pm 0.24 \mathrm{a}$ & $0.60 \pm 0.60 \mathrm{a}$ & $0.20 \pm 0.20 \mathrm{a}$ \\
B. bassiana WP 225 & $0.75 \pm 0.25 \mathrm{a}$ & $0.20 \pm 0.20 \mathrm{a}$ & $0.00 \pm 0.00 \mathrm{a}$ & $0.40 \pm 0.24 \mathrm{a}$ \\
B. bassiana WP 450 & $1.00 \pm 0.41 \mathrm{a}$ & $1.20 \pm 0.58 \mathrm{a}$ & $0.00 \pm 0.00 \mathrm{a}$ & $0.80 \pm 0.37 \mathrm{a}$
\end{tabular}

*Averages followed by the same letter in the column do not differ from each other by the Tukey's test $(p \leq 0.05)$.

TABLE 7 - Average number of Euetheola humilis larvae at stems or soil in 1 linear meter after application of the fungus Beauveria bassiana IBCB 66 with the formulations GR and WP in sugarcane, after harvest.

\begin{tabular}{lcccr}
\hline Treatments & \multicolumn{4}{c}{ Days after application } \\
\cline { 2 - 5 } & 0 & 21 & $0.40 \pm 0.40 \mathrm{a}$ & 100 \\
\hline B. bassiana GR & $1.50 \pm 0.96 \mathrm{a} *$ & $0.00 \pm 0.00 \mathrm{a}$ & $0.60 \pm 0.60 \mathrm{a}$ & $0.40 \pm 0.40 \mathrm{a}$ \\
B. bassiana WP 225 & $0.25 \pm 0.25 \mathrm{a}$ & $0.00 \pm 0.00 \mathrm{a}$ & $0.00 \pm 0.00 \mathrm{a}$ & $0.40 \pm 0.24 \mathrm{a}$ \\
B. bassiana WP 450 & $1.00 \pm 0.71 \mathrm{a}$ & $0.20 \pm 0.20 \mathrm{a}$ & $0.20 \pm 0.20 \mathrm{a}$ & $1.20 \pm 0.73 \mathrm{a}$ \\
Control & $0.00 \pm 0.00 \mathrm{a}$ & $0.00 \pm 0.00 \mathrm{a}$ &
\end{tabular}

*Averages followed by the same letter in the column do not differ from each other by the Tukey's test $(\mathrm{p} \leq 0.05)$.

Early results in reducing attacked sugarcane stems indicated a good potential of these fungi in biological control programs. The WP formulation of M. anisopliae, applied via liquid, was shown to have faster action than the GR formulation, and with predominance of $S$. levis larvae at the site, although it caused a decrease number in adults as well. The application of $M$. anisopliae GR, in granular form on the sugarcane ratoon, took longer to show results, but at 100 days after application, it was as effective as the WP formulation. None of the formulations or doses had any effect on the E. humilis larvae present in this study. However, the population of this group of insects only increased after 100 days of fungal application. The results confirm the claims of Macedo et al. (2006), in which the fungus $M$. anisopliae can be used to control S. levis in sugarcane field.

The results partially agree with Badilla and Alves
(1991), who obtained $92 \%$ control efficiency of S. levis adults in the field. Fernandez (1989) also reported that $B$. bassiana ESALQ-447 and $M$. anisopliae ESALQ-507 fungi caused greater than $45 \%$ mortality of $S$. levis adults within 16 days after inoculation of sugar cane tails under field conditions. However, the author pointed out that the fungus $B$. bassiana had greater virulence to $S$. levis compared to $M$. anisopliae, unlike the present study. Another field study by Simi et al. (2014) also reported that the B. bassiana IBCB 170 and M. anisopliae IBCB 383 fungi caused 28 and $30 \%$ confirmed mortality in S. levis adults. However, the authors achieved such efficiency only on $S$. levis adults, unlike the current study which was predominantly on larvae and adults. The methodology used by the authors aimed to control adults, as it depended on the displacement of the adults to the fungi-treated stems, something that the larvae would be unable to do. 
In contrast, the authors Vinha et al. (2019) in a similar study to the current one, reported that the fungi $M$. anisopliae and B. bassiana applied in the granulated formulation GR (rice + conidia) or liquid EC (in oil) at sugarcane were ineffective in controlling $S$. levis in the field, however the $B$. bassiana fungus at $1.0 \mathrm{~L} \mathrm{ha}^{-1}$ (EC) guaranteed the best control of $S$. levis, but with low residual period and efficacy. The results of Vinha et al. (2019) may have been negative due to the fungal methodology application used, which was different compared to the present study, that was performed with a ratoon cutter, promoting greater contact of the fungi with the insects.

Custódio et al. (2017) comparing the agrochemical and biological control of S. levis concluded that B. bassiana and $M$. asisopliae fungi were not effective in controlling $S$. levis, because the fungi did not reduce $S$. levis damage in the stalks of sugarcane plants, instead, the pesticide fipronil (active ingredient) reduced the infestation of $S$. levis and their damage in the stalks. Despite that, Evangelista et al. (2017) in a similar study did not control $S$. levis with the pesticide's ingredients (tiametoxam + lambda-cialotrina) and (fipronil + alfacipermetrina). Further studies in other conditions should be conducted to confirm the efficacy of $M$. anisopliae and B. bassiana in controlling S. levis. These trials will also allow a better understanding of fungi doses and different modes of application.

\section{CONCLUSIONS}

The fungus $M$. anisopliae was effective in controlling S. levis larvae and adults in the field and WP formulation had faster action than the GR, the dose of $225 \mathrm{~g}$ conidia $\mathrm{ha}^{-1}$ was enought to reduce $S$. levis population.

\section{ACKNOWLEDGEMENTS}

Authors wants to thank Vista Alegre mill for the sugarcane area ceded to this study.

\section{REFERENCES}

ALONSO-ZARAZAGA, M.A.; LYAL, C.H.C. Addenda and corrigenda to 'a world catalogue of families and genera of Curculionoidea (Insecta: Coleoptera)'. Zootaxa, v.63, n.1, p.1, 2002.

ANSARI, M.; TIRRY, L.; MOENS, M. Interaction between Metarhizium anisopliae CLO 53 and entomopathogenic nematodes for the control of Hoplia philanthus. Biological Control, v.31, n.2, p.172-180, 2004.

ANSARI, M.A.; SHAH, F.A.; TIRRY, L.; MOENS, M.Field trials against Hoplia philanthus (Coleoptera: Scarabaeidae) with a combination of an entomopathogenic nematode and the fungus Metarhizium anisopliae CLO 53. Biological Control, v.39, n.3, p.453-459, 2006.
ANSARI, M.A.; SHAH, F.A.; BUTT, T.M. Combined use of entomopathogenic nematodes and Metarhizium anisopliae as a new approach for black vine weevil, Otiorhynchus sulcatus, control. Entomologia Experimentalis et Applicata, v.129, n.3, p.340-347, 2008.

ANSARI, M.A.; SHAH, F.A.; BUTT, T.M. The entomopathogenic nematode Steinernema kraussei and Metarhizium anisopliae work synergistically in controlling overwintering larvae of the black vine weevil, Otiorhynchus sulcatus, in strawberry growbags. Biocontrol Science and Technology, v.20, n.1, p.99-105, 2010.

BARBERCHECK, M.E.; KAYA, H.K. Competitive interactions between entomopathogenic nematodes and Beauveria bassiana (Deuteromycotina: Hyphomycetes) in soilborne larvae of Spodoptera exigua (Lepidoptera: Noctuidae). Environmental Entomology, v.20, n.2, p.707-712, 1991.

BARBERCHEK, M.E.; KAYA, H.K. Interactions between Beauveria bassiana and the entomogenous nematodes, Steinernema feltiae and Heterorhabditis heliothidis. Journal of Invertebrate Pathology, v.55, n.2, p.225-234, 1990.

CÍCERO, E.A.S.; FERRAUDO, A.S.; LEMOS, M.V.F. Identificação de genes cry de Bacillus Thuringiensis no controle de Sphenophorus levis, o bicudo da cana-deaçúcar. Bragantia, v.68, n.4, p.817-23, 2009.

DEGASPARI, N.; BOTELHO, P.; ALMEIDA, L.; CASTILLO, H. Biologia de Sphenophorus levis Vaurie, 1978 (Col.: Curculionidae), em dieta artificial e no campo. Pesquisa Agropecuaria Brasileira, v.22, n.6, p.553-558, 1977.

FERNANDES, F.B. Controle microbiano do gorgulho da cana-de-açucar Sphenophorus levis VAURIE, 1978 (Col.:Curculionidae) com Beauveria spp. e Metarhizium anisopliae (METSH.) Sorokin, 1883. 1989. 144p. Dissertação (Mestrado em Entomologia) - Escola Superior de Agricultura Luiz de Queiroz - USP, Piracicaba, São Paulo, 1989.

GÜLTEKIN, L. A new record billbug, Sphenophorus abbreviatus (F.) (Coleoptera: Curculionoidea: Dryophthoridae) from Turkey. Journal of the Entomological Research Society, v.15, n.3, p.37-40, 2013.

HALL, D.G. Insects and Mites Associated with Sugarcane in Florida. The Florida Entomologist, v.71, n.2, p.138150, 1988.

LEITE, L.G.; TAVARES, F.M.; BOTELHO, P.S.M.; BATISTA FILHO, A.; POLANCZYK, R.A.; SCHMIDT, F.S. Eficiência de nematoides entomopatogênicos e inseticidas químicos contra Sphenophorus levis e Leucothyreus sp. em cana-de-açúcar. Pesquisa Agropecuária Tropical, v.42, n.1, p.40-48, 2012.

PEREZ, N.B.; LOPEZ-MARTINEZ, V.; JIMENEZGARCIA, D.; JONES, R.W. Determination of Spatial Distribution of Sphenophorus incurrens (Coleoptera: Curculionidae) using Gis in Morelos, Mexico. Florida Entomologist, v.97, n.1, p.285-287, 2014. 
PRECETTI; ARRIGONI, E.B. Aspectos bioecológicos e controle do besouro Sphenophorus levis Vaurie, 1978 (Coleoptera, Curculionidae) em cana-de-açúcar. . [S.1: s.n.], 1990.

SHAPIRO-ILAN, D.I.; DAVID， I.;JACKSON， M.; REILLY, C.C.; HOTCHKISS, M.W. Effects of combining an entomopathogenic fungi or bacterium with entomopathogenic nematodes on mortality of Curculio caryae (Coleoptera: Curculionidae). Biological Control, v.30, n.1, p.119-126, 2004.

SIMI, L.D. Controle de Sphenophorus levis e Conotrachelus humeropictus pelo uso combinado de nematoides e fungos entomopatogênicos. 2014. 107 p. Tese (Doutorado em Agronomia) - Faculdade de Ciências Agronômicas UNESP,Botucatu,São Paulo, 2014.

VINHA, F.B.; RODRIGUES, L.R.; PINTO, A.D.S. Controle do gorgulho-da-cana Sphenophorus levis com fungos entomopatogênicos em diferentes doses e formulações. Nucleus, v.16, n.1, p.329-335, 2019.

WOODRUFF, R.E. The hunting billbug, Sphenophorus venatus vestitus Chittenden, in Florida (Coleoptera, Curculionidae). Entomology Circular, v.45, n.9, p.1-3, 2001. 